\title{
Entre a repressão e a resistência - memória de jornalistas que trabalharam na imprensa de Porto Velho
}

\author{
Between the repression and resistance - memory of journalists worked who in the \\ press of Old Port
}

\author{
Aureni Moraes Ribeiro ${ }^{1}$ \\ (aurenipvh@gmail.com) \\ http://dx.doi.org/10.5216/cei.v14i1.21497
}

\begin{abstract}
Resumo
Este artigo visa entender como foi o impacto do regime militar pós 1964 nas redações de Porto Velho por meio da história oral de profissionais da imprensa que trabalharam durante este período considerado de exceção, aonde a liberdade de expressão foi cerceada. A década de 70 foi escolhida por fazer parte do chamado "anos de chumbo" considerado um dos períodos mais tristes da história do jornalismo no Brasil, onde houve a censura de forma mais intensificada meio encontrado para que houvesse a continuação do regime.
\end{abstract}

Palavras - chave: História. Memória. Jornalista. Repressão. Resistência.

\begin{abstract}
This paper aims to understand the impact of the military regime after 1964 in Porto Velho press. Through the analyses of oral history of profissionals who worked durring the period considered as exception, where the liberty of expression was cramped. The decade of 70 was chosen because it makes part of the called "years of lead" after the institutional act number 5, considered one of the sadder periods of the history of brazilian jornalism, where there was censure in a intensified form, a way found to keep the continuity of the regime.
\end{abstract}

Keywords: History. Memory. Journalist. Repression. Resistance.

\section{Introdução}

Este artigo abordar experiências pessoais e coletivas de jornalistas que trabalharam na década de 70 em jornais de Porto Velho. Esses profissionais são importantes, pois influenciaram a opinião pública e acompanharam mudanças significativas no então Território Federal de Rondônia, que estava em plena ditadura militar período considerado de exceção da liberdade de imprensa. A história oral de vida foi utilizada como referencial metodológico para a obtenção dos dados

\footnotetext{
${ }^{1}$ Bacharel pela Faculdade de Ciências Humanas, Exatas e Letras de Rondônia - FARO. Curso de Comunicação Social com habilitação em Jornalismo e licenciada em história pela Universidade Federal de Rondônia- UNIR.
} 
qualitativos. O uso de fontes orais foi importante na medida em que os jornalistas entrevistados testemunharam e participaram de um processo histórico que marcou a imprensa local. Através da história oral temática em conjunto com a fonte bibliográfica foi possível montar um panorama analítico do impacto da censura na imprensa em porto velho. A história oral temática é quase sempre usada como técnica, pois articula, na maioria das vezes, diálogos com outros documentos. (MEIHY, 2005).

Entre os objetivos deste trabalho é de que a fala dos depoentes possa contribuir com a história da imprensa em Rondônia, pois ainda são poucas as obras sobre censura. O artigo aborda os anos 70 onde acontece o apogeu e crise do Ato Institucional $\mathrm{n}^{\circ}$ 5. Ato este que impõe o cerceamento de expressão aos veículos de comunicação e também marca um período de grandes transformações sociais políticas, econômicas, ambientais e demográficas no Território Federal de Rondônia.

\section{Censura, liberdade e imprensa em questão}

A imprensa brasileira em seus 200 anos recém completos foi marcada entre relativa liberdade e repressão. Surgida em 1808 e consolidada a partir de 1821 é muito importante pela sua materialidade de servir como documento histórico e também pela força simbólica de suas palavras, capaz de modificar e influenciar lutas políticas e a opinião pública.

Muitos dos que escreviam para os jornais foram perseguidos especialmente nos regimes ditatórias da qual passou o Brasil. Primeiro no regime de Getúlio Vargas (1937-1945) e depois no regime militar implantado em 1964 e que perduraria até 1985. Esse período também foi chamado de ditadura militar, pois direitos civis foram cerceados e quem discordasse corria o risco de ser preso, torturado, exilado e até mesmo morto.

Vários Atos institucionais foram baixados pelo governo e ajudaram a impor o medo e a opressão a sociedade são eles: o Ato Institucional $n^{\circ} 1$, o Ato Institucional $n^{\circ} 2$, O Ato Institucional $\mathrm{n}^{\circ} 3$, o Ato Institucional $\mathrm{n}^{\circ} 4$ e o último e pior, que ratifica e endurece o regime o famoso AI-5 decretado no dia 13 de dezembro de 1968 pelo presidente Costa e Silva e que vigoraria até 1979.

Um golpe para a liberdade de expressão também foi a Lei de Segurança Nacional, e a Lei de Imprensa que diziam que todo o brasileiro era obrigado a cuidar de seu país até delatando prováveis insubordináveis. A lei de imprensa aumentou o controle aos meios de comunicação vigiando de 
perto escritores e jornalistas impedindo que tivessem liberdade de expressão. Adísia Sá no livro Jornalista Brasileiro, diz que:

(...) não se pode deixar de lembrar as arbitrariedades praticadas à sombra do poder, como empastelamento de jornais, agressão e até assassinato de jornalistas. Onde existisse um jornal no Brasil, aí estava o poder do Estado sob forma direta ou indireta, ou proteção e cobertura aos agressores de jornalistas. (SÁ, 1999, p.589).

Em todo o país ocorreram muitas prisões, torturas e mortes. A todos os que se mostraram contrários à política imposta. Dentre estes estão muitos jornalistas, alvos certos por trabalharem em um aparelho ideológico (Althusser, 1985).

Contrariamente a repressão ao livre pensamento muitos artistas como Caetano Veloso e Chico Buarque surgiram ou fizeram sucesso na ditadura militar. Os músicos e compositores encontraram na vida artística e cultural uma forma de resistência ao regime, apesar de toda opressão de censuras permanentes. A criatividade foi uma forma para burlar a censura aos veículos de comunicação. No jornalismo se destaca a imprensa alternativa que de forma irreverente atacava o regime vigente. O Pasquim desde o império foi uma forma de luta pela liberdade. O que incomodava a muitos. De acordo com Victor Viana (Apud, Sodré):

A imprensa era então panfletária e atrevida. Nos períodos de tolerância ou de liberdade, atingiu a grandes violências de linguagem e as polêmicas, refletindo o ardor apaixonado das facções em divergência, chegavam a excessos, a ataques pessoais, a insinuações maldosas. (SODRÉ, 1999, p. 84).

Repressão, censura e resistência são três conceitos ligados ao passado do jornalismo no Brasil, profissão esta que depende do livre pensamento e que foi profundamente marcada pela ditadura militar. A imprensa desde que foi criada foi um adversário real ou possível do poder estabelecido, ou seja, é um agente de mudanças da opinião pública e de paradigmas. O papel dos jornais para sociedade é muito importante, pois ajuda a dimensionar direitos sociais. Esse papel fica subdimensionado quando são implantados regimes ditatoriais, função que fica restrita ao grupo que está no poder.

Estudar a memória de um grupo, no caso de jornalistas é muito importante, pois pode oferecer dados relevantes para o contexto da época como explica Myriam Sepúlveda Santos. 
O passado é recuperado pelo presente através de processos de interação social. A compreensão do passado, neste caso, é composta de uma rede bem mais complexa de significados. São indivíduos em contato com outros indivíduos em determinado contextos sociais que trazem o passado para o presente. (SANTOS, 2003).

O resgate dessas memórias também ajuda a identificar elos, vínculos de pertencimento desta classe que participou do mesmo momento histórico. De acordo com Lovisolo "A memória histórica ou coletiva, repete-se, é fundamental para o sentimento nacional, para a consciência de classe (...) sendo constitutivas das lutas contra a opressão ou a dominação”. (LOVISOLO, 1989, p.17).

Os elementos básicos da comunicação de acordo com Aristóteles em seu livro a Arte da Retórica (Apud, Beltrão) são três: o comunicador (a pessoa que fala) a mensagem (o discurso) e o receptor (a pessoa que houve). Harold Lasswell complementa a colocação básica aristotélica em cinco estágios: QUEM diz o QUE em que CANAL a QUEM e com que EFEITO. Raymond Nixon modifica o esquema de Lasswell introduzindo mais dois elementos: as intenções do comunicador e as condições da recepção.

Luiz Beltrão em Teoria Geral da comunicação (1977) diz que para que ocorra o processo comunicacional tem que existir uma comunidade atuante, ou seja, o elemento que toma a iniciativa de provocar em outrem a iniciativa da saída da inércia. Para atuar o comunicador precisa de algumas faculdades: domínio da consciência em nível correspondente ao objetivo da mensagem em outras palavras deve ter capacidade de pensar e liberdade de trabalhar o pensamento, o conhecimento da sua posição dentro do sistema sociocultural.

O jornal dentre os meios de comunicação é considerado o primeiro veículo das massas e que trabalha de acordo com os elementos de Aristóteles. Dentre a sua importância vale ressaltar que:

Desde os seus primeiros dias, os jornais foram um adversário real ou possível do poder estabelecido especialmente na sua própria percepção. Imagens fortes da história do jornalismo referem-se à violência contra jornalistas editores e tipógrafos. Sublinham a luta por liberdade de publicar, muitas vezes num movimento mais amplo para a liberdade, a democracia e os direitos dos cidadãos. (McQUAIL, 2000, p.22).

Denis Macquail entende que houve uma progressão histórica para uma maior liberdade de imprensa, apesar de haver grandes retrocessos uma vez e outra. E havendo uma substituição da violência por restrições legais. 
O contexto histórico e atual em todas as perspectivas discutidas assume um apoio geral a liberdade de imprensa, significando o direito de publicar sem censura e nem licença prévia e sem incorrer em multas, nos limites das outras obrigações legais (McQUAIL, 2000, p. 148).

Desde o século XVIII muitos movimentos revolucionários e reformistas também viram na liberdade de imprensa uma bandeira de luta uma forma de defender ideais e suas causas. A luta pela liberdade na história teve muitos protagonistas que foram responsáveis de alguma forma pelo cerceamento do direito de publicação. São eles a igreja e o governo.

René Dreifuss no livro 1964: A conquista do Estado também comenta sobre os mecanismos de centralização do poder por meios de veículos de comunicação.

Os canais de persuasão e as técnicas mais comumentes empregadas compreendiam a divulgação de publicações, palestras, simpósios, conferências de personalidades famosas por meio da imprensa, debates públicos, filmes, peças de teatrais, desenhos animados, entrevistas e propagandas no rádio e na televisão. A elite orgânica do complexo IPES/IBAD também publicava diretamente ou através de acordo com varias editorias uma série extensa de trabalhos incluindo livros, periódicos, jornais, revistas e folhetos. Saturavam o rádio e a televisão com suas mensagens políticas e ideológicas. Os jornais publicavam seus artigos e informações. (DREIFUSS, 1986, p.232)

Dreifuss (1986) ainda comenta que o complexo IPES/IBAD era muito articulado conseguindo controlar de perto as agências de notícias e os canais de informação em todo o país.

O Instituto Brasileiro de Ação Democrática (IBAD) foi criado em 1959 e o Instituto de Pesquisa e Estudos Sociais (IPES) em 1961. Ambos tinham a função de persuadir a sociedade quantos aos valores do capitalismo e deter a manifestação e o avanço do comunismo. Incentivador do pensamento anti Goulart, integrou movimentos sociais da base de oposição, entidades essas que foram fundamentais para o golpe de 1964.

Ainda neste contexto de mecanismos de centralização podemos citar a obra Aparelhos Ideológicos do Estado de Luis Althusser que enfoca a centralização a partir do uso da ideologia.

Aparelhos ideológicos do Estado um certo número de realidades que apresentam-se ao observador imediato sob a forma de instituições distintas e especializadas (...) podemos pelo momento considerar como aparelhos ideológicos do Estado as seguintes instituições (...) AIE religioso (o sistema das diferentes igrejas ), AIE escolar (o sistema de diferentes "escolas" públicas e privadas), AIE familiar, AIE jurídico, AIE político (o sistema político, os diferentes partidos), AIE sindical, AIE 
de informação (a imprensa, o rádio, a televisão, etc...), AIE cultural ( letras Belas Artes, esportes, etc...). (ALTHUSSER, 1985, p.68).

Desta forma todo governo ditatorial que queira deter poder e mantê-lo sobre controle terá que fazer uso dos aparelhos ideológicos do Estado "nenhuma classe pode, de forma duradoura, deter o poder do Estado sem exercer ao mesmo tempo sua hegemonia sobre e nos aparelhos ideológicos do Estado" (ALTHUSSER, 1985, p.71).

O Brasil viveu momento semelhante na ditadura Estado Novista implantado por Getúlio Vargas com a criação do Departamento de Imprensa e Propaganda (DIP), entidade criada para exercer o controle da comunicação social e que ampliou a eficácia da ideologia dominante. Neste cenário:

O DIP exercia o monopólio dos veículos de informação, procurando garantir a uniformidade das mensagens e eliminar a contra-propaganda para os efeitos da comunicação se ampliassem. Nas redações dos órgãos de imprensa a presença física dos censores foi uma realidade no primeiro momento do estado novo (GOULART, 1990, p. 21).

Com a implantação do regime militar no Brasil em 1964, os meios de comunicação de massa tiveram um papel fundamental como instrumentos de controle social é o que diz Bernardo Kucinski em seu livro A Síndrome da Antena Parabólica. Vale ressaltar que:

Sob o regime autoritário (1964-79), a mídia foi acessória nas tarefas de controle social, exercidas principalmente pela repressão física, silenciamento de vozes dissidentes e expurgos de lideranças populares. Sob a democracia, dada a ilegitimidade das formas coercitivas de controle, a repressão tornou-se instrumento secundário de controle e a mídia passou a ser procurada pelas elites dominantes como o meio principal de controle social. (KUCINSKI, 1998, p.18).

Síndrome da antena parabólica seria o resultado do regime autoritário sobre os jornalistas nas quais os resultados foram à implantação de uma autocensura cicatrizes que se prolongaram até os dias de hoje gerando "uma cultura jornalística na qual se destaca a compulsão a unanimidade, o simulacro, o desprezo pela verdade (...)" (KUCINSKI, 1998, p.51).

Muitos jornalistas resistiram à expansão das ideologias do AI-5, principalmente nos anos (1968-1972) que veio endurecer o regime. Os mais combativos e críticos foram demitidos e sofreram o modelo de repressão que geralmente era pela força. Morto em pleno regime militar o jornalista Vladimir Herzog se tornou um símbolo de luta e resistência. 
A imprensa neste momento se divide em imprensa oficial e alternativa. A imprensa alternativa foi uma forma de resistência que muitos escritores e jornalistas encontraram para lutar contra a censura e a favor da liberdade de imprensa.

Apesar, porém, de todo esse poder, a imprensa não conseguiu escapar a medidas reguladoras e restritivas, tornadas mais necessárias em virtude mesmo de seu prestígio. Atuando constantemente sobre a opinião pública o jornal, sendo muitas vezes a leitura única de algumas pessoas, valia, no dizer de um publicista, como "um veneno sem antídoto". Verdade que as constituições proclamam solenemente a sua liberdade, mas a declaração não impediu a adoção de medidas limitativas. Nunca houve para a imprensa um regime de liberdade absoluta, desde que os seus excessos sempre se conceituaram como criminosos e passíveis de penalidade. (LIMA SOBRINHO, 1997, p.28).

Nos quase 20 anos que o país viveu o período ditatorial a imprensa viveu sob forte vigilância, muita repressão e censura. O que não impediu formas de resistência ao regime.

\section{0 conceito de notícia e reportagem}

Há centenas de conceitos para se definir o que é notícia. Podemos dizer com certeza que é a matéria-prima dos veículos de comunicação, e está atrelada a informação. Nilson Lage no livro "Ideologia e Técnica da Notícia" define notícia como "O relato de uma série de fatos a partir do fato mais importante e este, de seu aspecto mais importante (...) os de verdade ou de interesse humano" (LAGE, 2000, p.36). Lage também afirma que a notícia é um bem simbólico e nela estão impregnadas ideologias.

De acordo com o Manual da redação da Folha de São Paulo no verbete notícia. A notícia é o puro registro dos fatos. Existem critérios para definir sua importância são eles:

Ineditismo (a notícia inédita é mais importante do que a já publicada). 2) Improbabilidade (a notícia menos provável é mais importante do que a já publicada). 3) Interesse (quanto mais pessoas possam ter sua vida afetada pela notícia, mais importante ela é). 4) Apelo (quanto maior a curiosidade que a notícia possa despertar mais importante ela é). 5) Empatia (quanto mais pessoas puderem se identificar com o personagem e a situação da notícia, mais importante ela é). 6) Proximidade (quanto maior a proximidade geográfica entre o fato gerador da notícia e o leitor, mais importante ela é). (MANUAL DA FOLHA DE S. Paulo, 2001, p.43). 
No jornalismo impresso também há a presença da notícia clássica ou lead que é a forma de organização da notícia. A notícia deve responder as seis perguntas no primeiro parágrafo: Quem? Quê? Quando? Onde? Por quê? Como? Esta fórmula criada pelo jornalismo norte americano para padronizar os textos, continua sendo até hoje os principais elementos da notícia.

Mário Erbolato no livro técnicas de decodificação em jornalismo (1987, p. 60) diz que as notícias têm que respeitar a alguns critérios: proximidade, Marco Geográfico, Impacto, Proeminência (ou celebridade), Aventura e conflito, Consequências, Humor, Raridade, Progresso, Sexo e idade, Interesse Pessoal, Interesse Humano, Importância, Rivalidade, Utilidade, Política Editorial do Jornal, Oportunidade, Dinheiro, Expectativa ou suspense, Originalidade, Culto de Heróis, Descobertas e invenções, Repercussão, Confidências.

Conforme Lage (2000) o estilo reportagem compreende desde a simples complementação da notícia até uma expansão que situa o fato em suas relações mais óbvias com os outros fatos antecedentes, consequentes ou correlatos. Ou seja, qualquer notícia pode ser complementada e virar uma reportagem.

No caso de uma reportagem sobre um fato histórico se chama efeméride que de acordo com o verbete do Manual da Folha (2001) é "Texto publicado em jornal por motivo de aniversário de evento importante na história: revolução, aniversário de país ou cidade, centenário da morte de artista etc.” (MANUAL DA FOLHA DE S. PAULO, 2001, p.64).

\section{Contexto histórico década de 1970}

A década de 1970 marcou de forma decisiva um período de grandes transformações na história do então território Federal de Rondônia e influenciou as subsequentes. É quando ocorre o grande surto migratório para a colonização. A cidade de Porto Velho começa a bater sucessivos recordes de crescimento demográfico. Os migrantes vêm em busca de terras para a agricultura. A BR 364 foi importante, pois interligou Rondônia ao Centro-Sul. Dando condições ao povoamento. Os projetos de colonização do INCRA (Instituto Nacional de Reforma Agrária) foram os responsáveis pela vinda dos colonos do Sul do país como o Ouro Preto, Projeto Ji-paraná, projeto Sidney Girão, Vilhena e Burareiro. Os projetos de colonização causaram grande desmatamento, invasões de áreas indígenas e também conflitos agrários. Também e a partir da década de 1970 que começa a corrida do ouro na região. O preço do ouro em alta atrai para região muitos garimpeiros em busca de riqueza. A partir daí se criam inúmeros garimpos ao longo do rio Madeira. O Cel. 
Jorge Teixeira Governador do Território Federal de Rondônia desde 1979, cria o Estado de Rondônia em 22 de dezembro de 1981, a instalação se dá em 4 de janeiro de 1982, sendo também o próprio Jorge Teixeira o primeiro governador do Estado.

Na década de 1970 o território federal de Rondônia possuía 116.620 habitantes de acordo com o IBGE (Instituto Brasileiro de Geografia e estatística).

\section{A censura nos jornais em Porto Velho - resultado pesquisa}

As entrevistas feitas com profissionais da imprensa no período estudado a década de 1970, apontaram para três formas de censura: a censura política, a censura empresarial e a censura econômica que estiveram presentes nos jornais em Porto Velho.

Além das entrevistas com os depoentes conforme salientei foi realizado um trabalho de pesquisa bibliográfica, para dar sustentação teórica às falas.

A primeira forma de censura da qual os entrevistados falaram foi à censura política. Censura esta que impactou profundamente os meios de comunicação, devido ao período de "ditadura" da qual foi imposta o país. Na fala do jornalista Lúcio Albuquerque que trabalhou no jornal a Tribuna percebe-se claramente este fato “(...) o problema e que a gente enfrentava uma barra. A Tribuna foi um dos três jornais com censura prévia e censura econômica que trabalhei. Censura prévia era o seguinte no período chamado de revolucionário ou ditadura ou quartelada, sei lá como chamam, também anos de chumbo, mais eu acho que anos de chumbo a gente vive hoje (...) naquele tempo o que acontecia, você produzia um texto na redação aí seu texto tinha que passar no censor. Censor era dois funcionários que a mando do governo, liam toda sua matéria. Se eles discordassem de você marcavam de vermelho e não saia, então você tinha que produzir outro texto encima daquele mesmo. E ainda não diria amenizando as palavras, mais driblando”.

Esta fala mostra que houve censura, porém uma censura mais branda se comparada a outras regiões do país onde a censura foi mais forte. O jornalista Ciro Pinheiro que trabalhou no jornal Alto Madeira disse que "ameaça de morte e morte eu nunca vi falar na imprensa de Porto Velho, censura houve, por exemplo, naquele tempo a gente recebia telex de vez em quando que dizia tal matéria não pode ser publicada, esse era o tipo de censura que existia naquele tempo”.

A censura através dos tempos foi justificada pelos governantes como um meio ou um instrumento que o Estado dispõe para garantir a paz pública a ordem e a harmonia social. Discurso falacioso, mas que durante um regime é a forma que esses administradores encontram para garantir 
a permanência do regime. Constata-se isso nas falas dos dois colaboradores, onde mesmo estando em um Território afastado dos grandes centros era preciso ter cautela com a imprensa por menor que fosse. Pois sua difusão de pensamentos ou qualquer notícia contrária a política vigente poderia por em risco a "paz" e a "ordem".

Conforme Maria Aquino (1999, p.15) encarava-se como necessário o controle da informação a ser divulgada, para preservar a imagem do regime num exercício de ocultação que passa, inclusive pela negação de visibilidade ao leitor de suas próprias condições de vida.

As lembranças de Silvio Persivo, colaborador do Alto Madeira nos anos 70 são as seguintes "Aqui a ditadura foi mais suave, mandavam retirar matérias. Vinham nas redações e diziam isso aqui não publica. Sempre de matérias políticas ou de que atentassem a moral e aos bons costumes, na época era mais colaborador do que qualquer outra coisa. Na realidade a parte mais acentuada da ditadura vivi como estudante de economia em Fortaleza, então quando cheguei aqui já era formado, já tinha passado a época mais acentuada de 67 a 72. Cheguei aqui em 75 já havia um processo de distensão".

O regime militar como no Estado Novo também criou órgão para coagir a imprensa ou qualquer manifestação de pensamento. Neste período foi criado o SNI (Serviço Nacional de Informação) que visava detectar e punir qualquer tentativa explícita ou implícita de "subversão" a ordem instaurada segundo Maria Aparecido Aquino (1999). O SNI tinha suas ramificações regionais às chamadas segundas seções de informação das forças armadas. Estas eram as que atuavam em Porto Velho capital do Território Federal de Rondônia.

Sobre o período da repressão a imprensa Luiz Antônio de Araújo escritor e jornalista que trabalhou como colaborador no jornal Alto Madeira recorda "Eu nem sei se Porto Velho viveu a revolução, só houve aqui três sou quatro casos de perseguição política, sendo o único jornalista Inácio Mendes do Combate, a história de Porto Velho sempre foi muito controversa isso aqui sempre foi reduto de militares. Tinha que ter muita coragem para militar causas."

Houve vozes dissonantes em Porto Velho, entre as citadas do Jornalismo está Inácio Mendes citado no livro "Brasil Nunca Mais" da arquidiocese de São Paulo. Inácio Mendes era dono do jornal o Combate. Semanário que segundo o depoente Silvio Persivo era "uma metralhadora giratória contra Deus e o mundo”. Lúcio Albuquerque lembra que “o jornal do Inácio Mendes foi empastelado por participação de colegas que tão aí, são hoje assessores da democracia, foram lá 
empastelar. O jornal dele também foi apreendido na saída. Quando ele saia era obrigado a se esconder na rua”.

Tem se em Inácio Mendes um modelo de resistência ao regime ainda que duvidosa, pois como se vê na fala ele era contra "Deus e o mundo". Não especificamente contra o regime imposto no momento. A forma de jornalismo feito por ele era o "acusatório", o que acabou desagradando a alguns políticos da época. Não muito diferente de algumas formas de jornalismo praticadas hoje, que em vez de informar "acusa" sem mostrar os contrapontos.

Importante ressaltar que o jornalismo mesmo nos dias de hoje é controlado por meios jurídicos, por exemplo, como a lei de imprensa feita durante o regime militar em 1967. Michel Foucault no livro a "Ordem do discurso" ressalta que:

(...) em toda sociedade a produção do discurso é ao mesmo tempo controlada selecionada, organizada e redistribuída por certos números de procedimentos que tem por função conjurar seus poderes e perigos, dominar seu acontecimento aleatório, esquivar sua pesada e temível materialidade. (Michel Foucault, 1996, p.9).

Nesta citação de Michel Foucault percebe-se o que podemos chamar de interdição. Significa que em uma sociedade não se tem o direito de dizer tudo em qualquer circunstância. Em um regime de exceção isso se acentua. Mas é necessário sempre ter em mente que os discursos estão longe de serem neutros ou transparentes. Na ditadura militar o que se percebe claramente é que por mais que houvesse vozes sufocadas, o regime não conseguiu destruí-las por menor que tenham sido sua participação, como no caso do jornal o Combate em Porto Velho.

Houve um desnivelamento de discurso na sociedade neste momento. Mas o que não impediu que tivessem outros além do oficial. Lúcio Albuquerque em seu depoimento narra bem esse fato "uma vez aqui nos fizemos um texto absurdo, havia uma proibição de anunciar determinados fatos. Aí ao menos assim 'ontem não aconteceu tal coisa conforme informação do governo, por que ontem na realidade, o seu fulano de tal não se envolveu em tal' coisa era uma maneira de afirmar negando então passava na censura, por meio disso aí. Era comum estarmos trabalhando e chegar alguém da polícia federal ou sei lá, e chegava na redação oito da noite com um papelzinho, um quarto de papel, sem assinatura de nada, onde estava escrito 'proibido veicular informação sobre tal coisa' aí a saída ontem não aconteceu tal coisa, conforme informação de tal órgão. Então tivemos que utilizar a inteligência para driblar a censura”. 
Com relação sobre ao engajamento político de jornalistas não se verificou nenhuma associação que pudesse fazer frente ao regime militar. Filiações a partidos políticos, associações, sindicatos ou a Federação Nacional de Jornalismo (FENAJ). "Nos não tínhamos neste período nenhum sindicato de jornalistas. Nós tivemos aqui uma associação em 1978. A FENAJ nunca fez nada por Rondônia, nem agora. Só vem aqui em época de eleição e manda dizer que existe (...) eu nunca fui filiado a partido político nenhum. Você tinha direito de ter seu partido, mas, não tinha direito de usar isto para influenciar seu texto na redação" Lúcio Albuquerque; "Não havia sindicato foi fundado depois, os jornalistas não estavam afiliados a nada, também só tinha meia dúzia de jornalistas e só tinha dois jornais" Ciro Pinheiro; "Nessa época houve um movimento para formar o sindicato, não havia coisa partidária só haviam dois partidos políticos um do governo e outro da oposição o MDB" Silvio Persivo.

Com relação ao acesso as fontes de informação os entrevistados disseram não encontrar tanta resistência. "O acesso à fonte de informação não era como hoje que a informação está por todo lado. As notícias custavam muito a chegar. A própria televisão tinha acabado de chegar, e só víamos a programação gravada por videoteipe. O jornalismo era praticamente de notícias locais e o resto era de notícias captadas da rádio (...) com relação ao acesso a fonte de informações oficiais, normalmente os caras nem falavam tinha que insistir muito, por que não queriam dar a notícia. O poderio militar era muito grande. Eles só se interessavam pela imprensa quando interessava a eles" Silvio Persivo; "O acesso à fonte de informação era tranquilo" Ciro Pinheiro.

Percebe-se claramente a diferença de visão dos dois jornalistas. Um percebe resistência por parte dos militares, o outro não percebe nada de diferente. Lembrando que já existiam assessores de imprensa na época, o próprio Ciro Pinheiro foi assessor de Imprensa do governador Jorge Teixeira. Em sua tese de Doutorado “A censura, o censurável, e o censurado" Sheila Maria Féres explica que:

(...) os veículos de comunicação de massa fornecem aos homens a possibilidade de reflexão e questionamento sobre os mecanismos que os movem e consequentemente a possibilidade de interromper ou alterar seus movimentos. O desafio ao "status quo" é claro e daí a preocupação de muitos governantes em estabelecer a censura e estes veículos. (FÉRES, 1980, p.36).

É importante ressaltar que durante a pesquisa foi identificado outras formas sutis de censura que foi imposta não só a imprensa, mas como a outros veículos de comunicação. Como a censura econômica que era a concessão ou retirada de publicidade oficial dos veículos. Ciro Pinheiro lembra 
“(...) naquele tempo existia a censura politica, hoje existe a censura econômica, entendeu. Os jornais têm um contrato com o governo e, por exemplo, dependendo do tipo de material que se veicula o governo não paga o contrato” No período do regime já se percebe que este tipo de censura econômica imposta, prende os veículos a divulgar somente o que era conveniente ao governo. Sobre este tema de censura econômica Montezuma Cruz também ressalta a censura econômica. "Em Porto Velho, a censura se manifestou de outra forma: pelo boicote financeiro (...) Fui descobrir, tempos atrás, que a Assessoria de Segurança e Informações da então estatal Companhia Vale do Rio Doce elaborou uma lista de jornais nos quais o governo não deveria anunciar. Tenho cópia da lista, por sinal, bem detalhada. Da Amazônia, eles sugeriam que não se fornecesse publicidade oficial para A Notícia (Manaus) e A Tribuna (Porto Velho). De Cuiabá, a vítima foi o extinto Correio da Imprensa. A lista é uma nojeira. Você encontra lá dezenas de publicações que, pelo fato de publicar verdades, desagradavam os militares. A lista que estava nas mãos do SNI (Serviço Nacional de Informações), afirmava com todas as letras que os jornais ali descritos eram "contestadores".

Além de ouvir jornalistas do "período de chumbo" da ditadura a pesquisa também contemplou a fala do dono de um veículo de comunicação. O mais antigo em funcionamento de Porto Velho o jornal Alto Madeira. A respeito do período histórico trabalhado, O empresário Euro Tourinho disse que "Nunca tivemos problema nenhum com os militares. As pessoas estranham quando falo que nossa convivência com eles foi muito boa. Pacifica. Nunca tivemos nada. Por que eu sou um elemento disciplinado. Senão fosse disciplinado e lógico que teria. Se você tem as forças nas mãos, você vai impor essa força. Agora em plena democracia você vê cada absurdo que as autoridades cometem né. Põe gente na cadeia, perseguem. Quando não pode perseguir prende abertamente, exclui manda perseguir por trás, bota fiscalização em cima e a maneira de perseguir. Então com a revolução é o seguinte eles mandavam nos jornais e dizia olha não mexa nesse tema aqui e não visite outros temas. E simplesmente obedecia. Se desobedecesse podia ser punido, ser preso. Mas eu não publicava”.

O colaborador nesta fala demonstra tranquilidade para falar do tema não demonstrando nenhuma mágoa ou "ferida" do regime militar. "Os jornalistas nesse período se comportaram pacificamente. A ditadura em Porto Velho ocorreu amena. Os que eram contra nada diziam por que tinham medo. Aqui a revolução não teve grande impacto.” Frisa Euro Tourinho. 
A respeito dos temas que não podiam ser veiculados, Euro Tourinho recorda "Por exemplo, a questão do Che Guevara quando foi morto, foi uma recomendação. Não pode Che Guevara. Você não vai criticar a revolução. Dizer que a Revolução está matando, está prendendo arbitrariamente. Isso você não podia falar. Não podia falar mal da revolução. Então não se falava bem, mas também não se falava mal."

Percebe-se que os mecanismos de centralização do regime funcionam muito bem no caso da imprensa. Aqui não houve censura intensificada. Mas o silêncio que se implantou também pode ser considerado sua manifestação, pois, se havia silêncio é por que alguma forma de censura estava sendo imposta senão, pelos órgãos centralizadores, mas pelos donos destes veículos. Euro Tourinho demonstra em sua fala por que "A ordem vinha do comando geral dos militares. Cada área tinha um comandante. Porto Velho tinha um. Então a ordem partia de lá e chegava ao jornal e dizia olha não mexe nisso. Era um censor. Ele chegava e dizia por ordem do comando não toca nesse assunto aqui e obedecia. Para que eu ia fazer resistência. Para ser preso e dizer que era machão. Não".

Os jornalistas também ficavam restritos as ordens de seus patrões e deviam fazer apenas seu trabalho sem discordar. Isto pode explicar a passividade com a qual alguns encararam o regime. Quanto a descumprir ordens dos órgãos oficiais “É lógico se o jornal e meu eu o impediria. Poderia até ser demitido, dependendo da categoria de jornalista, se fosse um bom jornalista se não fosse costumeiramente desobediente só era chamado atenção. ” Recorda Euro Tourinho.

Outra forma de censura muita vezes invisível aos leitores de jornais impressos e a censura empresarial, ou também podemos chamar de "linha editorial". Esta por sua vez filtra os temas e os assuntos que são pertinentes a empresa jornal. Assuntos de interesse público podem ficar de fora se não forem do interesse da empresa. Maria Aparecido Aquino (1999, p.16) diz que não existem dados sobre o outro lado da censura a empresarial. A que se refere aquela que aparece sob forma de "linha editorial" e se concretiza nos impedimentos a liberdade de expressão do jornalista, algemado pela "voz do dono" e se manifesta através dos "interesses superiores" da empresa. Desta forma o jornalista como comunicador social sofre pressão de vários fatores externos do dono do jornal (proprietário), do departamento comercial, de instituições e da clientela.

A censura que a imprensa sofreu desde a época do regime militar ocasionou o que podemos chamar de autocensura, que prevalece de uma forma ainda silenciosa nas redações hoje. Resquício desse período de exceção. A censura cria a autocensura. Segundo Maria Aparecida Aquino: 
Uma das maiores preocupações dos profissionais da imprensa na época referia-se a introjeção da censura, numa explicitação da autocensura, mesmo após o termino de sua vigência, ou seja, após tantos anos de convivência com "ordens superiores" ou com o censor instalado nas redações impedindo ou mutilando o exercício de seu trabalho, temiam os jornais que retirada a censura prévia, a autocensura viesse tomar o seu lugar, como um alter ego, bloqueando a sua produção e a função de informar o leitor. (AQUINO, 1999, p.16).

A questão fundamental a se discutir é que a censura tem diversas facetas e pode se apresentar de variadas formas, mesmo hoje em plena democracia. No livro "Censura a imprensa e estado autoritário" Maria Aquino (1999, p.17) diz que o autoritarismo deve ser analisado no plano da longa duração histórica. Se institucionalmente ele pode ser definido em marcos cronológicos rígidos, socialmente ele tende a proliferar seus tentáculos ramificando-se por todo o tecido social, apresentado grandes dificuldades de desativação mesmo depois de encerrada a sua fase institucional.

A questão fundamental para tirar da autocensura é ética, pois sem ética não há preocupação com a verdade e com os interesses sociais. A tolerância com práticas não éticas acaba ferindo o princípio de liberdade de imprensa.

\section{Considerações Finais}

As entrevistas com os jornalistas que trabalharam na imprensa de Porto Velho na década de 1970, cidade pertencente ao então Território Federal de Rondônia, apontaram para o fato de que houve sim censura a imprensa durante o regime militar. Censura está que pode ser encarada como branda, ou seja, não tão intensa como em outras regiões do país onde a perseguição foi mais ferrenha. Os entrevistados não recordaram mortes ou ameaças de mortes, processos ou condenações relacionadas ao período estudado. A censura identificada foi apenas aos textos. Aonde se tinha frequência de censores nas redações verificando os textos. A censura também foi feita através de telex, com mensagens que informavam os assuntos que não podiam virar matérias.

As conclusões a respeito da resistência dos jornalistas ao regime apontaram para o fato de que ela foi mínima, sendo o único caso relatado pelos entrevistados o do jornalista Inácio Mendes do jornal Combate, que foi perseguido e fazia do seu jornal um meio para "atacar" personalidades políticas da época. A interpretação que se faz a respeito do comportamento dos jornalistas neste 
período e que eles foram cooptados pelo regime, não havia nenhuma forma de engajamento e nem interesse de aderir a nenhum partido político ou a movimentos que fizessem frente ao regime.

Para entender o impacto que a ditadura teve nos jornais da época e sobre os jornalistas é importante salientar que Porto Velho ainda não era uma cidade de grande porte. Os meios de comunicação ainda eram bem incipientes. Tudo isto dificultava de alguma forma o levante contra o regime que havia sido implantado.

A única forma de captação de fonte de notícias de âmbito nacional era através da rádio escuta, ou seja, escuta de notícias dos programas da rádio. Mesmo assim todas as notícias que chegavam até os jornalistas já vinham de alguma forma censurada pelos mecanismos de censura instalados no restante do país.

Além das entrevistas com os jornalistas conforme salientei foi realizado uma ampla pesquisa bibliográfica que deu sustentação teórica a pesquisa.

Pelas análises realizadas pude considerar que todo o processo de repressão vivido durante o regime ou movimento militar, principalmente pós Ato Institucional $\mathrm{N}^{\circ} .5$ tem sequelas até os dias de hoje na imprensa em Porto Velho. Aparece de forma silenciosa como a censura econômica e a censura empresarial.

\section{Referências}

ANDRADE, Maria Margarida de. Introdução á metodologia do trabalho científico: elaboração de trabalhos na graduação. 7. ed. São Paulo: Atlas, 2005.

ALTHUSSER, Louis. Aparelhos ideológicos de Estado. 2. ed. Rio de Janeiro: Edições Graal, 1985.

AQUINO, Maria Aparecida de. Censura, Imprensa e Estado autoritário (1968-1978): o exercício cotidiano da dominação e da resistência: O estado de São Paulo e movimento. Bauru: EDUSC, 1999.

Arquidiocese de São Paulo. Brasil: nunca mais. 12. ed. Prefácio de Dom Paulo Evaristo Arns. Petrópolis. 1985.

BARBOSA LIMA SOBRINHO, Alexandre José. O problema da imprensa. 3. ed. São Paulo: Edusp: Com - Arte, 1997.

BELTRÃO, Luiz. Teoria Geral da Comunicação. Brasília, Thesaurus, 1977. 
DREIFUSS, René Armand. 1964: A conquista do Estado: ação política, poder e golpe de classe. Ed. Vozes. Petrópolis - RJ. 1981.

ERBOLATO, Mario L. Técnicas de Codificação em Jornalismo. 3. ed. Petrópolis: Vozes, 1987.

FÉRES, Sheila Maria. A censura, o censurável, o censurado. São Paulo, 1980. Tese apresentada a Fundação Escola de Sociologia e Política de São Paulo.

FOUCAULT, Michel. A ordem do discurso. Edições Loyola, São Paulo. Brasil, 1996.

GOULART, Silvana. Sob a verdade oficial. São Paulo: Marco Zero, 1990.

KUCINSKI, Bernardo. A síndrome da antena parabólica: ética no jornalismo brasileiro. São Paulo: Ed. Fundação Perseu Abramo, 1998.

LAGE, Nilson. Ideologia e técnica da notícia. 3. ed. Florianópolis: UFSC, 2000.

LOVISOLO, Hugo. A memória e a formação dos homens. In: "Revista de Estudos Históricos 1987/3". CpDoc/FGV (Orgs.), Rio de Janeiro, v. 12, n.3, p.16-28, São Paulo, Ed. Revista dos tribunais Ltda. Edições Vértice: 1989/3.

FOLHA DE S. PAULO. Manual de Redação. Publifolha, 2001.

McQUAIL, Denis. Teoria da comunicação de massas. Lisboa: Fundação Calouste Gulbenkian, 2003.

MEDINA, Cremilda de Araújo. Entrevista: o diálogo possível. São Paulo: Ática, 1990.

MEIHY, José Carlos Sebe Bom. Manual de História Oral. 5. ed. São Paulo: Loyola, 1995.

SÁ, Adísia. O jornalista brasileiro: federação nacional dos jornalistas profissionais, de 1946 a 1999. Fortaleza: Edições Fundação Demócrito Rocha, 1999.

SANTOS, Roberto Elísio dos. As teorias da comunicação: da fala à internet. São Paulo: Paulinas, 2003.

SANTOS, Myriam Sepúlveda dos. História e memória: o caso da Ferrugem. Departamento de Ciências Sociais/ UERJ.

SODRÉ, Nelson Werneck. História da Imprensa no Brasil. Rio de Janeiro: Mauad, 1999. TEIXEIRA, Marco Antônio e FONSECA, Dante. História Regional (Rondônia). Porto Velho RO, Rondoniana, 1998.

\section{Depoimentos}

ARAÚJO, Luiz Antônio de. Entrevista feita em Porto Velho. 11 de outubro de 2008.

LUCIO, Albuquerque. Entrevista feita em Porto Velho. 04 de outubro de 2008.

CRUZ, Montezuma. Entrevista feita em Porto Velho. 30 de outubro de 2008.

PERSIVO, Silvio. Entrevista feita em Porto Velho. 11 de outubro de 2008.

PINHEIRO, Ciro. Entrevista feita em Porto Velho. 11 de outubro de 2008.

TOURINHO, Euro. Entrevista feita em Porto Velho. 31 de outubro de 2008. 